\title{
Reklamcılık Literatüründe Egemen ve Eleştirel Yaklaşımlara Yönelik Karşılaştırmalı Bir Alan Çalışması: Lisansüstü Tezler ve Makaleler Üzerine Bibliyometrik Bir Analiz
}

\author{
Cihan BECAN ${ }^{l}$
}

\section{Özet}

Türkiye'de çoğunlukla üniversitelerdeki İletişim Fakültesi bünyesinde verilen reklamcılık eğitiminin niteliği son yıllarda üzerinde sıklıkla durulan ve kritiği yapılan konular arasında yer almaktadır. Buradan hareketle reklamcılık eğitimine ışık tutması bakımından bu çalışmada, reklamcılık literatüründeki çalışmalar arasında temel yaklaşımlar bakımından karşılaştırmalı bir araştırma yapılması amaçlanmıştır. Lisansüstü tezler ve makaleler her zaman bir akademik literatürdeki araştırmaların özelliklerini ve yönelimlerini tespit edebilmede ve eğitimin niteliği hakkında önemli veriler sunmaktadır. Bu çalışmada, 2008 - 2018 yılları arasında Türkiye'de reklamcılık alanında sunulmuş lisansüstü (yüksek lisans ve doktora) tezleri ve ulusal hakemli makaleleri yıllara göre sayısal değişimleri, bağlı oldukları anabilim ve Anasanat dalları, temel araştırma konuları, dayandıkları temel yaklaşımlar ve kuramsal arka plan üzerine eğildikleri araştırma yöntemleri ile araştırma teknikleri ve içerdikleri anahtar kelimeler açısından bibliyometrik çözümlemeye tabi tutulmuştur. Araştırma sonuçlarından bazıları göstermektedir ki tez ve makale sayısı son yıllarda ciddi bir biçimde artarken disiplinler arasılık özelliği yükselmekte, ayrıca reklamcılık alanındaki konular yaşanan çevresel gelişmelere göre önem kazanmaktadır. Reklamcılık alanında yapılan çalışmalarda çoğunlukla egemen yaklaşımın benimsendiği ve nitel araştırmalara ağırlık verildiği görülmektedir.

Anahtar kelimeler: Reklamcılık, bibliyometri, reklam araştırmaları, lisansüstü tezler

\section{A Comparative Study for Administrative and Critical Approaches in the Literature of Advertising: A Bibliometric Analysis on Graduate Thesis and Papers}

\begin{abstract}
The education of advertising in Turkey, which has been principally studied under the Department of Communication, has been made a great progress and has been frequently discussed in recent years. From this point of view, in the sense that it provides an insight to advertising education, the main aim of the study is to make a comparative research between studies in the advertising literature by administrative and critical approaches. Graduate theses (graduate and doctoral) provide valuable data to ascertain the characteristics and tendencies of research in an academic field and the quality of advertising education. In this research, graduate theses and papers on the national-refereed journals that have been completed between 2008 and 2018 (Turkey) in advertising studies analyzed through a bibliometric method according to a series of specifications such as the number of theses and papers per year, the disciplines which the graduate study is undertaken, research topics, basic approaches, theoretical bases examined research methods and techniques, language and keywords. With regard to the result of the study, it points that while the quantity of theses and articles and characteristic of interdisciplinary has increased dramatically and moreover, the topics in the advertising field has gained importance in accordance with the environmental factors. It is also seen that studies on advertising are mostly adopted administrative approach and they are focused on qualitative researches.
\end{abstract}

Key words: Advertising, bibliometrics, advertising studies, graduate thesis

1 Dr. Öğr. Üyesi, İstanbul Aydın Üniversitesi, Halkla İlişkiler ve Tanıtım Bölümü, cihanbecan@aydin.edu.tr 


\section{Giriş}

Türkiye'nin dünya genelinde en dikkat çeken sektörlerinden birisi reklamcıllk sektörüdür. Güncel bir o kadar da yoğun olan reklamcılık alanında iyi bir entelektüel altyapıya sahip olması zorunlu görünmektedir. Yaratıcı kültür ekonomisi içerisinde önemli bir hacme sahip olan bu sektörün insan kaynakları ihtiyacı geçmişte genel olarak farklı disiplinlerden mezunlarla karşılanmıştır. Günümüzde özellikle reklamcılık lisans ve lisansüstü programlarının açılmasıyla gerek sektörün ihtiyacına yönelik gerekse entelektüel eğitim vermeye yönelik uzmanlaşma çabası dikkat çekmektedir.

Disiplinler arası bir alan olarak değerlendirilen reklamcılık disiplini, özellikle yirminci yüzyılın yarısından sonra, özel sektörün ve kamu kuruluşlarının yanında kar amacı gütmeyen kuruluşlarda dahi hayati bir öneme sahip olduğunu göstermiştir. Kamu, özel sektör veya kar amacı gütmeyen kuruluşlar hedef gruplarına günümüzde kendi varlığından haberdar edebilmek ve kendi çıkarı doğrultusunda bilgilendirmek ve ikna etmek gibi bir amacının bulunması reklamcılık alanına stratejik bir konum kazandırmıştır. $\mathrm{Bu}$ yönüyle reklam, kapitalist sistemde ticari kuruluşların önemli bir parçası haline gelen, hedef tüketicileri bilgilendirmeyi veya etkilemeyi amaçlayan mesajlar bütünü olarak tanımlanırken (Wunderlich ve Warrier 2007: 25), diğer taraftan "tüketiciyi ihtiyaç duyduğu belli bir ürün ya da hizmeti satın almaya yöneltmek amacıyla, ürünler/hizmetler hakkında fikirler oluşturulması ve/veya iletilmesi” olarak tarif edilmektedir (Elden vd. 2005: 64).

Toplumda reklamı etkileri bakımından olumlu ve olumsuz gören görüşler bulunmaktadır. Kimileri reklamı hayatımızda olmazsa olmaz olarak görüp işletmelerin piyasada sürekliliğini sağlama ve istihdam oluşturması gibi yönlerden olumlu olarak değerlendirirken, kimileri ise insanları tüketime teşvik ettiği, ihtiyaç yokken varmış gibi göstermesi gibi nedenlerden dolayı olumsuz olarak eleştirmektedirler. Reklamcılığa, satılmak üzere piyasaya sürülen ürünlerle ilişkisi olmayan duyguları hedef alan akıldışı bir sistem olarak bakılmaktadır. Öte yandan reklam taraftarları insanların reklamlara aldırmakta tamamen özgür olduklarını, reklamların duyguları sömürmediğini, bunun nedeninin pek çok reklam kampanyasının tüketiciyi cezb etmekte başarısız olduğunu söylemektedir. Reklamcılık alanında yapılan çalışmalarda ele alınan konular, bu sosyal etkiler bakımından olumlu ve olumsuz gören görüşler için yönetimsel ve eleştirel yaklaşımlardan yararlanarak pek çok farklı boyutta işlenmektedir.

Buradan hareketle bu çalışmada, reklamcılık literatüründe lisansüstü tezler ve bilimsel makaleler ölçeğinde yönetimsel ve eleştirel yaklaşımlara yönelik karşılaştırmalı bir alan çalışması yapmak amaçlanmaktadır. Alanın gelişimini ve bu alandaki bilimsel bilginin üretiminin ne şekilde sağlandığını aktaran lisansüstü tezler ve makaleler 2008 - 2018 yılları arasını kapsayacak şekilde bibliyometrik analiz tekniğiyle taranacaktır. Bu doğrultuda araştırma, reklamcılık alanında 2008 - 2018 yılları arasında yazılan lisansüstü tezlerini ve hakemli dergilerde yayımlanan makaleleri tasnif etmeyi, söz konusu bu çalışmaların alana katkısının hangi konularda ve ne düzeyde/sıklıkta olduğunu tespit 
etmeyi ve ele alınan konuların egemen (yönetimsel) ve eleştirel yaklaşımlar açısından karşılaştırma yapmayı sağlayacaktır.

\section{Literatür Taraması}

Kapitalizmin genişlemesi, bilim ve teknolojideki değişimler toplumda meydana gelen olayları doğal ve toplumsal sebepleri olduğunu ortaya koymaktadır. Ekonomik üretim araçlarını elde eden burjuva sınıfı, egemen güç haline geldikten sonra kendi denetimindeki bilimi, çalışan sınıfları denetlemek ve var olan üretim ilişkilerini devam ettirmek için kullanmıştır. Bunun üzerine kitleleri denetleme ve yönlendirme ihtiyacının artmasıyla, iletişim bilimlerini de örgütlü bir araştırma faaliyeti olarak daha fazla ön plana çıkarmıştır. Onun için iletişim bilimlerinde sosyal olguları ve gelişmeleri açıklayacak tek bir kuram yoktur. Farklı sınıfların farklılaşan çıkarları, farklı kuramlar aracılığıyla açıklanabilmektedir. İletişim alanında var olan toplumsal düzeni meşrulaştırma ve sürdürmeyi amaçlayan kuram ve yaklaşımlar "egemen” kuramlar olarak adlandırılırken, mevcut sistemi ve iletişimi eleştirel bir tarzda irdeleyen çalışmalar ise "eleştirel kuramlar" olarak nitelendirilmektedir.

Ampirik veya yönetim araştırmaları ekonomik ve siyasi kurumların siyasi yapısını, iktidarın merkezileşmesini, egemen bağımlı ilişkilerini ve sınıf çıkarlarını çalışma dışında tutmaktadırlar. Eleştirel yaklaşımların dayanak noktasını ise siyasi ve ekonomik ilişkilerin asimetrik yapısı oluşturmaktadır (Melody ve Mansell 1983: 104). Bu safhada iki çeşit yaklaşımı ayırt etmek yararlı olacaktır. Williams (1981) şu çeşitleri önermektedir: a) Politika ve piyasa kararlarını gösteren sonuçları araştıran işlemsel çalışmalar; örneğin reklam sonrası etkiler için 'tutum' yoklamaları, anketler, testler; yayın araştırmalarında programlara verilen tepki çalışmaları; hükümet siyasası gibi 'meseleler' de politikayla ilgili oy kullanma. b) Eleştirel çalışmalar ise diyelim ki şiddet, siyasi yayın, hem özel hem genel toplumsal etkinin yaratıldığı düşünülen (reklam gibi) dikkate değer farklı türlerin medyada temsiline bakar.

Özellikle kitle iletişim araştırmalarında, pozitivist, davranışçı, nicel yöntemlerle ve ağırlıklı olarak yapısal-işlevselci paradigmayla karakterize olan toplumsal-bilimselci "anayol" iletişim çalışmalarının toplumsal olguları göz ardı eden, var olan sistemin dengesini sürdürme yollarını araştıran araştırma mantığına ve hipotezlerine karşı; Marksizm, psikanaliz, sınıf çatışması, kültürelcilik, yapısalcılık, göstergebilim gibi farklı kaynaklardan beslenen ve iletişimi toplumsal süreçlerden ve yapılardan ayırmadan bütüncül bir kavrayışla yaklaşan, farklı yaklaşımları bir araya toplayan kapsayıcı bir niteleme olarak görülmektedir (Mutlu, 2012: 89).

Eleştirel ve yönetimsel araştırmaların arasında tarihsel bir ayrılık göze çarpmaktadır. Yönetimsel gelenek bütün bilgilerin kaynağının duyumsal tecrübe olduğu görüşüne dayanarak aklı, deneyden bağımsız olarak bilgi kaynağı kabul eden yaklaşıma karşı çıkmaktadır. Ampirik metot tarihsel süreçleri, iktidarı ve egemen ideolojiyi incelememektedir. Buna karşın eleştirel araştırmalar, çoğunlukla toplumsal çatışma, eşitsizlik, kurumsal güdüler, iktidar gibi kategorileri dikkate almaktadır. Eleştirel 
iletişim çalışmaları, insanın davranışını ve ilişkilerin karmaşıklığını anlamak için ampirik metodun kullandığı fiziksel olgunun ötesinde açıklamalar yapılması gerektiğinin altını çizmektedir. (Yaylagül 2010: 29).

$\mathrm{Bu}$ iki tip gelenek sorun seçim tiplerine, kullandıkları araştırma yöntemine, araştırmacının ideolojisine göre farklılaşmaktadır. Yönetimsel gelenek, araştırma sorunu olarak bir örgütün eylemlerinin nasıl daha etkin hale getirilebileceğini incelemektedir. Örneğin bir otomobilin nasıl daha iyi reklamının yapılacağı, yani bir şirketin karlılığını nasıl artırılacağını araştıran bir anlayıştır. Eleştirel anlayışla, ilgili toplumsal katmanların kolektif ihtiyaçlarının karşılanmasında toplumsal kurumların nasıl yeniden biçimlendirileceği araştırılmaktadır. Bu gelenekte kitlelerden korku, kitlelerin toplumsal egemenlik süreçlerine seçim ve sivil örgüt süreçleriyle katılmalarını yaygınlaştırarak geniş tabanlı bir meşrulaştırma elde etmek ve sürdürmek politikası içinde anlamlandırılmaktadır (Erdoğan ve Alemdar 2002: 45).

Eleştirel yaklaşımlar, toplumsal eşitsizlik ve iktidar sorunuyla ilgilenmektedirler. Politika iktidar gücünü elde etmek ve toplumsal eşitsizlikleri yeniden üretmek için bir araçtır. İktidarın ele geçirilmesinde ve sürdürülmesinde iletişim faaliyetlerinin ne gibi bir etkinliği bulunduğu bu yaklaşım içerisinde yer alan temel sorunlardandır. Bunun yanında iktidarın kullanılmasında bilgi üretimi ve dağıtımı üzerindeki iktidarın kontrolü sorunu üzerinde de odaklanılmaktadır (Slack ve Allor 1983: 215). Eleştirel yaklaşımların kökeni belki de kendi koşullarını değiştirmek amacıyla reaksiyon gösteren insana, dolayısıyla insanın varoluşuna kadar uzanmaktadır (Erdoğan ve Alemdar 2002: 58). Murdock (1993), eleştirel paradigmaların geniş bir bölümünün iletişim kuramında yer almasına karşılık, iletişim kuramının modernlik tasarısını temel çözümleme konusu yapan toplum kuramı içindeki güncel tartışmalardan yeterince yararlanmadığını belirtmektedir.

İkinci Dünya Savaşı sonrasında kitle iletişim araştırmalarına hâkim olan yönetsel yaklaşım, bireylerin egemen ideoloji çerçevesinde kurumlar ile uyum içerisinde davranışlar sergilediğini, bunun en önemli nedeninin de kapitalist dünyadaki kurumların kar, rekabet ve meşruiyet ilişkileri üzerinde kurulu olması ile gündelik yaşamın bireysel çıkarlar temelinde örgütlenmiş olması arasındaki bağda yattığını belirtmektedir. Yönetsel yaklaşımın sosyal etkiye ilişkin temel kabulleri, piyasa ve kamuoyu araştırmalarında da benimsenmiş; pazarlama araştırmaları kapsamında reklamların iletildiği mecranın derinliği, kompozisyonu ve geribildirim kapasitesi önem kazanmıştır. Yönetsel yaklaşımda reklamın amacına ulaşıp ulaşmadığının belirlenmesi, reklamın etkisinin nasıl biçimlendiğinin ya da reklam mesajının nasıl iletildiğinin ve işlendiğinin bilinmesi ile mümkündür (Yılmaz 2002: 42).

Genel itibariyle literatürde ana akım reklam çalışmaları Kuzey Amerika merkezlidir ve bu çalışmaların ezici çoğunluğu reklamı, ikna ve pazarlama yönüyle ele almaktadır. Ancak oldukça sınırlı olmakla birlikte, reklamı kültürel bir olgu ve reklam metinlerini de kültürel bir metin olarak ele alan eleştirel reklam çalışmaları da literatürde mevcuttur. Dyer (1982: 7) reklamın çelişkili bir yönünün altını 
çizmektedir: "Reklam bir yandan sürekli tüketim önererek maddi bir motivasyon sağlarken, diğer yandan paradoksal bir şekilde çağdaş reklamcılık bize dünyanın yeterli olmadığını söylemektedir. Reklam, kültürün dilini, imajlarını, değerlerini ve mitlerini kullanır”. Leiss vd. (1990: 5) reklamın sadece iş yaşamını ilgilendiren ekonomik bir olgu olarak görülmeyeceğini; aynı zamanda modern kültürün ayrılmaz bir parçası olduğunu savunmaktadır. Sherry (1987: 445)'e göre ise reklamcıllı̆ın görünen yüzeydeki işlevi ürünlerin ve hizmetlerin satın alınmasını teşvik etmek; görünmeyen işlevi ise bireyleri tüketim kültürü içinde toplumsallaştırmaktır.

Reklam ile ilgili eleştirel çalışmaların, Frankfurt Okuluyla birlikte, finansal kapitalizme geçiş ve hizmet sektörünün tüm dünyadaki yükselişiyle beraber son dönemde hızla arttığı ve çeşitlendiği görülmektedir. Frankfurt Okulu tarafindan yerinde bir yaklaşımla medya endüstrisi içinde ele alınan reklam, günümüzde ideolojik ve kültürel yeniden üretimin gerçekleştiği bir metin olarak da okunmaktadır. Frankfurt Okulu tarafından "kapitalizmi meşrulaştıran kültürel düzenlemeler" olarak yorumlanan reklam ve medya endüstrisinin içerikleri, İngiliz Kültürel Çalışmaları'nın açtığı yolda, "kapitalizmin hâkim değerlerinin yeniden üretimini sağlayan ideolojik metinler" olarak da çalışılmaktadır. Eleştirel reklam çalışmalarının bakış açısıyla yapılan reklam analizlerinde görülmektedir ki, artık reklamlar tüketiciye "şu ürün şöyle faydalıdır, böyle hesaplıdır, şu işe yarar" söylemi yerine, toplumsala dair imaj değerleriyle seslenmektedir. Bu nedenle reklam metinlerinin analizinde, hangi toplumsal değerlerin ürünün imaj değeri olarak yeniden üretildiği görülmektedir (Dağtaş 2009: 47).

\section{Reklamcılık Literatüründeki Lisansüstü Tezlere ve Makalelere İlişkin Araştırma}

\section{Araştırmanın Amacı ve Önemi}

Lisansüstü tezler ve bilimsel makaleler, içeriği ve hazırlanışı itibariyle herhangi bir bilimsel alanda yapılan üst düzey akademik çalışma niteliğindedir. Bu yayınların bilimsel bilgi açısından iki temel fonksiyonu bulunmaktadır. İlk olarak çalışılan alandaki bilgi birikiminin değerlendirilmesini sağlamaktadır. Diğer bir ifadeyle çalışılan alanla ilgili üretilen bilimsel bilginin genel bir değerlendirilmesini yapması sahip olduğu ilk işlevdir. İkinci fonksiyonu ise tezlerde ve makalelerde ele alınan tartışmayla biçimlenen araştırmanın sonucunda yeni bir bakış açısı getirmesi veya doğrudan bilimsel bilgi üretmesidir (Yaşın ve vd., 2017; 455). Bu bakımdan lisansüstü tezlerin ve bilimsel makalelerin çalışılan alanın gelişimine ve bu alandaki bilimsel bilginin üretimine doğrudan olumlu bir katkısının olduğunu söylemek mümkündür. Buradan hareketle araştırma, reklamcılık alanında 20082018 yılları arasında yazılan lisansüstü tezlerini ve hakemli dergilerde yayımlanan makaleleri tasnif etmeyi, söz konusu bu çalışmaların alana katkısının hangi konularda ve ne düzeyde/sıklıkta olduğunu tespit etmeyi ve ele alınan konuların egemen (yönetimsel) ve eleştirel yaklaşımlar açısından karşılaştırma yapmayı amaçlamaktadır. 
Çalışmada bu temel amacı gerçekleştirebilmek için şu sorulara yanıt aranmaktadır:

a) Reklamcılık alanında yazılan lisansüstü tezlerin ve makalelerin yıllar itibariyle dağılımı nasıldır?

b) Reklamcılık alanında yazılan lisansüstü tezlerin anabilim dallarına göre dağılımları nasıldır?

c) Reklamcılık alanında yazılan lisansüstü tezlerin türlerine göre dağılımları ne şekildedir?

d) Reklamcılık alanında yazılan lisansüstü tezlerin ve makalelerin araştırma yöntemine göre dağılımı nasıldır?

e) Reklamcılık alanında yazılan lisansüstü tezlerde ve makalelerde işlenen konulara göre dağılımı nasıldır?

f) Reklamcılık literatüründe yararlanılan egemen ve eleştirel yaklaşımların dağılımı nedir?

g) Reklamcılık literatüründe yararlanılan egemen ve eleştirel yaklaşımların lisansüstü tez ve makalelere göre dağılımı nasıldır?

$\mathrm{Bu}$ araştırma temel itibariyle, reklamcılık literatüründe yapılan akademik çalışmalara ilişkin, hangi konular üzerinde yoğunlaşıldığının ilk kez mercek altına alınması bakımından önemli bir rol oynamaktadır. Bununla beraber, reklamcılık iletişimi alanındaki çalışmaları egemen ve eleştirel olmak üzere iki farklı yaklaşıma göre karşılaştırarak fikir edinmek ve Türkiye'deki reklamcılık akademisi konusunda bilgilere ulaşmak üzere lisansüstü seviyedeki öğrencilere, eğitimcilere ve akademisyenlere 1şık tutması açısından önemini artırmaktadır.

\section{Araştırmada Kullanılan Yöntem ve Veri Toplama Tekniği}

$\mathrm{Bu}$ çalışmada, Yükseköğretim Kurumu Ulusal Tez Merkezi (YÖKTEZ) veri tabanında reklamcılık alanında yayımlanan lisansüstü tezlerin ve bilimsel, ulusal hakemli dergilerde yayımlanan makalelerin çeşitli parametreler doğrultusunda bibliyometrik analizinin gerçekleştirilmesi uygun görülmüştür. Bu amaç doğrultusunda, çalışmada veri toplama tekniği olarak içerik incelemesi kullanılmıştır. Çalışmada Türkiye'de 2008-2018 yılları arasında yayımlanan lisansüstü tezlerin bibliyometrik özellikleri "tür, yıl, anabilim dalı, işlenen konu, araştırma yöntemi, yararlanılan yaklaşımlar" açısından incelenmiştir. Makaleler ile ilgili tarama dönemi de lisansüstü tezlerle zamansal tutarlı1ık sağlanabilmesi adına aynı periyod olarak ele alınmıştır. Araştırmada elde edilen veriler istatistiki yöntemlere uygun hale getirilmiştir. Araştırmada tanımlayıcı istatistikler uygulanmış, yüzde ve frekans değerleri belirlenmiştir.

Bir bilim dalı veya uygulama alanında yapılan çalışmaları, önceden belirlenen çeşitli parametreler çerçevesinde, bir sistem dahilinde düzenleyerek geniş kapsamlı listeler oluşturmaya ve sayısallaştırarak niceliksel analizler yapmaya olanak tanıyan bibliyometrik araştırmalar (Broadus 1987; 
Özel ve Kozak 2012) literatürün gelişiminde ve ilgili alandaki genel eğilimlerin ortaya konulmasında birçok araştırmacının üzerinde önemle durduğu bir araç rolü görmektedir (Palmer vd. 2005).

Bibliyometri, akademik yayınların değişik öğelerinin sayısal analizler ve istatistikler aracılığıyla incelenmesi, kitaplar ve diğer iletişim platformlarına uygulanması olarak ifade edilmektedir (Pritchard 1969; Zan 2012). Bibliyometrik araştırmalarda akademik yayınların belirli unsurların analiz edilerek bilimsel iletişime ilişkin çeşitli bulgulara ulaşılması söz konusudur (Al ve Coştur 2007). Bibliyometri, bilim insanları, bilimsel araştırma ve araştırma projesi yürütenler, kütüphaneciler, yöneticiler ve karar vericiler tarafindan sıklıkla başvurulan bir araştırma tekniğidir (Özel ve Kozak 2012). Bibliyometrik analizler; tanımlayıcı nitelikte olabileceği gibi (belirli bir yılda yayımlanan yayınların sayısının belirlenmesi) değerlendirici nitelikte de (bir yayının kendisinden sonra gelen çalışmaları nasıl etkilediğini belirlemek için atıf analizi yapılması) olabilirler (Çetinkaya ve Çetin 2016).

Veri analizinde kategorik veri analizi tekniklerinden içerik analizinden yararlanılmıştır. Bu amaçla, toplanan verinin önce kavramsallaştırılması, daha sonra da ortaya çıkan kavramlara göre mantıklı bir biçimde düzenlenmesi ve buna göre veriyi açıklayan temalara ulaşılması gerekmektedir. Çünkü içerik analizinde temelde yapılan işlem, birbirine benzeyen veriyi belirli kavramlar ve kategoriler çerçevesinde bir araya getirmek ve bunları okuyucunun anlayabileceği şekilde düzenleyerek yorumlamaktır (Yıldırım ve Şimşek 2005: 227). Bu analiz sırasında izlenen aşamalar aşağıda özetlenmektedir:

a-Birinci aşama: Reklamcılık alanında hazırlanan lisansüstü tezler (yüksek lisans ve doktora tezleri) ve bilimsel makaleler yıllara, yapıldıkları üniversitelere, anabilim dallarına, özgün dillerine, işlenen konulara ve araştırma yöntemlerine göre kategorize edilmiştir.

b-İkinci aşama: Reklamcılık alanında hazırlanan lisansüstü tezler ve bilimsel makaleler; a) Egemen ve b) Eleştirel yaklaşımlar olmak üzere temel iki yaklaşıma ayrılarak kodlanmıştır. Buna göre de tezler yıllara, yapıldıkları üniversitelere, özgün dillerine ilgili oldukları konulara göre kategorize edilmiştir.

Türkçe literatürde reklamcılık alanında yapılan bibliyometrik çalışmalar incelendiğinde, lisansüstü tezleri ve makaleleri bu bağlamda değerlendirmeye alan araştırmalara rastlanamamıştır. $\mathrm{Bu}$ anlamda böyle bir çalışmanın yapılmasının bu boşluğu dolduracağı düşünülmektedir. Diğer bir amaç olarak reklamcılık ile ilgili çalışmaların yönünü ve eğilimlerini göstermesi açısından da çalışmanın literatüre katkı sağlayacağı ve bu alanda çalışacak araştırmacılara kolaylık sağlayacağı düşünülmektedir. 


\section{Araştırmanın Varsayımları ve Kısıtları}

Araştırmanın ilk varsayımı, ülkemizdeki üniversitelerde 2008-2018 döneminde reklamcılık alanında yapılan tezlerin tümünün Yüksek Öğretim Kurumu (YÖK) Ulusal Tez Merkezi Elektronik Tez Arşivinde tam ve doğru olarak kayıtlı olduğu kabul edilmektedir. Ancak YÖK'ün, tez veri tabanını ayrıntılı bir şekilde 2000'li yılların ortasından itibaren oluşturduğu göz önüne alınırsa, belli eksiklikler olacağı göz önüne alındığında 2008 yılından öncekine ait tezlerin tam olarak veri tabanında kayıtlı olmayacağı varsayılmıştır. Bu konuya ilişkin araştırmanın varsayımı, 2008-2018 döneminin Türkiye'de reklamcılık alanına lisansüstü çalışmalar yoluyla yapılan bilimsel katkının 10 yıllık bu süreçte nasıl gelişme gösterdiğini ve bu gelişmeye hangi üniversitelerin ne tür katkı yaptığını görmeyi sağlayacak genişlikte bir zaman dilimi olduğudur.

Araştırmanın bir başka varsayımı, lisansüstü tezlerin ve makalelerin tümünün bilimsel yöntem kullanılarak yapılmış olduğudur. Tezlerin bilimsel yöntem kullanılarak yapılmış olması, veri toplama, düzenleme ve analiz çalışmaları, tezlerin konuları, konu başlıkları (adları) ve anahtar sözcükleri esas alınarak yapıldığı için önem taşımaktadır. Araştırmada incelenen lisansüstü tezlerinin seçiminde öncelikli olarak bibliyometrik analizi yapılması için zaman sınırlaması gerekliliği dikkate alınmış, bu çerçevede son on yılda yazılan lisansüstü tezler ve makaleler incelenmiştir. Dolayısıyla araştırmanın bir kısıtı, araştırma kapsamında bulunan toplam 1.295 tezin tamamının görülmesinin, okunmasının, (sadece çok gerekli olanlar dışındakilerin) öz/özet bölümlerinin incelenememiş olmasıdır. Bunun doğal nedeni tez sayısının fazlalığıdır. Araştırmada incelenen lisansüstü tezlerin seçiminde Tez Merkezi’nin veri tabanında "reklamcılık" anahtar kelimesiyle yapılan tarama sonucunda ortaya çıkan tezler analize tabi tutulmuştur. Araştırmanın diğer bir kısıtı ise lisansüstü tezlerle aynı zaman dilimini kapsaması bakımından 2008 yılı öncesi faaliyete geçmiş ve halen aktif yayında olan bilimsel, ulusal hakemli dergiler incelenmiş ve reklamcıllı̆̆ içeren makaleler ele alınmıştır. Ulusal hakemli dergilerin belirlenmesinde ise günümüzde akademik atanma kriterleri açısından önemli bir rol oynayan ULAKBİM veri tabanı baz alınmıştır. Makaleler tarandığında ise tezlerdeki gibi anahtar kelime girilemeyeceğinden araştırmanın bir kısıtı olarak, mutlaka başlıkta reklamcılık geçmesi zorunluluğu getirilmiştir.

\section{Araştırmanın Evreni ve Örneklemi}

Araştırmanın evrenini, konu hanesine reklamcılık yazıldığında Yükseköğretim Kurulu Başkanlığı'nın tez veri tabanında liste halinde dökülen toplam 1,295 adet tez ve ulusal hakemli dergilerde taranan tüm reklam alanındaki makaleler oluşturmaktadır. Türkiye'de 2008 - 2018 yılları arasında reklam ile ilgili taranan 693 tez ile yine aynı dönemi kapsayıp, 2008 y1lı öncesinde yayın hayatına başlayan ve devam eden ulusal hakemli dergilerde taranan 99 makale olmak üzere toplam 782 yayın araştırmanın örneklemini oluşturmaktadır. Toplam 693 tezden izinli olmayan 40 tez ile doğrudan 
reklamcılıkla ilgisi olmayan 32 tez araştırma dışı bırakılarak 621 tez araştırma kapsamında incelenmiştir.

\section{Araştırmanın Bulguları}

Türkiye'de 2008-2018 yılları arasında reklam ile ilgili toplam 693 yüksek lisans ve doktora düzeyinde tez çalışması yapılmıştır. Bu tezlerin \% 5,77’lik (40’’1) dilimi izinli olmayan statüde iken \% 4,77'lik (32'si) bölümü ise doğrudan reklamcılıkla ilgisi olmadığı için geriye kalan izinli olan 621 tez incelenmiş olup (bkz. Tablo 1), yıldan yıla değişmekle birlikte söz konusu 10 y1llık dönem boyunca yılda ortalama 50,4 yüksek lisans tezi; 11,7 doktora tezi tamamlanmıştır. Yüksek lisans düzeyinde en fazla tez üretilen yıl 2016 (\%14,29), doktora tezinde en fazla tez üretilen yıl 2010 ve 2017 (\%11,97) yıllarıdır. 2012 yılı ise hem yüksek lisans $(\% 6,35)$ hem de doktora $(\% 5,98)$ düzeyinde en az üretimin yapıldığı dönem olarak geçmektedir. Tablo 2 incelendiğinde zaman içerisinde inişli çıkışlı bir eğilim gözlense de lisansüstü tezlerin 2013 yılı itibariyle artış yaşandığı gözlemlenmektedir. Ayrıca yüksek lisans tezleri araştırmaya alınan toplam 621 tez içerisinde \% 81,16'lık dilimi kapsarken, doktora tezleri ise \% $18,84^{\prime}$ lük orana sahiptir. Bunun temel sebebinin yüksek lisans eğitiminin doktora eğitimine göre daha kısa sürede tamamlanması ve doktora tezinin araştırma sürecinin daha kapsamlı olması nedeniyle uzun bir süreye yayılması olarak bakılabilir.

Tablo 1. Lisansüstü Tezlerin Yayın Durumu

\begin{tabular}{|c|c|c|}
\hline TEZ YAYIN DURUMU & Frekans & Yüzde \\
\hline İzinli olan & 621 & $89,61 \%$ \\
\hline İzinli olmayan & 40 & $5,77 \%$ \\
\hline Doğrudan reklamcılıkla ilgisi olmayan & 32 & $4,77 \%$ \\
\hline TOPLAM & 693 & $100,00 \%$ \\
\hline
\end{tabular}


Tablo 2. Lisansüstü Tezlerin Yayımlandığı Yıl

\begin{tabular}{|c|c|c|c|c|}
\hline \multirow[t]{2}{*}{$\begin{array}{c}\text { TEZiN } \\
\text { YAYIMLANDIĞI YIL }\end{array}$} & Frekans & \multirow[t]{2}{*}{ Yüzde } & Frekans & \multirow[t]{2}{*}{ Yüzde } \\
\hline & Y. Lisans & & Doktora & \\
\hline 2018 & 60 & $11,90 \%$ & 4 & $3,42 \%$ \\
\hline 2017 & 68 & $13,49 \%$ & 14 & $11,97 \%$ \\
\hline 2016 & 72 & $14,29 \%$ & 12 & $10,26 \%$ \\
\hline 2015 & 42 & $8,33 \%$ & 13 & $11,11 \%$ \\
\hline 2014 & 49 & $9,72 \%$ & 13 & $11,11 \%$ \\
\hline 2013 & 38 & $7,54 \%$ & 8 & $6,84 \%$ \\
\hline 2012 & 32 & $6,35 \%$ & 7 & $5,98 \%$ \\
\hline 2011 & 37 & $7,34 \%$ & 10 & $8,55 \%$ \\
\hline 2010 & 33 & $6,55 \%$ & 14 & $11,97 \%$ \\
\hline 2009 & 42 & $8,33 \%$ & 11 & $9,40 \%$ \\
\hline 2008 & 31 & $6,15 \%$ & 11 & $9,40 \%$ \\
\hline TOPLAM & 504 & $100,00 \%$ & 117 & $100,00 \%$ \\
\hline
\end{tabular}

Yapılan araştırmada 2008 - 2018 yılları arasında incelenen 99 ulusal makalenin en fazla yayımlandığı yıl 2018 yılı olarak dikkat çekmektedir. Onu sırasıyla 2010 ve 2008 yılı takip etmektedir. Lisansüstü tezlere göre makalelerin daha yoğun yayımlandığ y1llar arasında birbirini takip eden bir eğilim görülmemekte ve yıllar arasında çok fazla bir fark gözükmemektedir. Makalelerin sayısının lisansüstü tezlerin toplam sayısına göre az olmasının temel sebebi, araştırma kapsamına alınan zaman diliminde incelenebilecek hakemli dergilerin sayısının oldukça sınırlı olmasından kaynaklanmaktadır.

Tablo 3. Araştırma Kapsamında Incelenen Makalelerin Yayımlandığı Yıl

\begin{tabular}{|l|c|c|}
\hline MAKALENIN YAYIMLANDIĞI YIL & Frekans & Yüzde \\
\hline 2018 & 17 & $17,17 \%$ \\
\hline 2017 & 7 & $7,07 \%$ \\
\hline 2016 & 9 & $9,09 \%$ \\
\hline 2015 & 7 & $7,07 \%$ \\
\hline 2014 & 8 & $8,08 \%$ \\
\hline 2013 & 8 & $8,08 \%$ \\
\hline 2012 & 8 & $8,08 \%$ \\
\hline 2011 & 4 & $4,04 \%$ \\
\hline 2010 & 14 & $14,14 \%$ \\
\hline 2009 & 7 & $7,07 \%$ \\
\hline 2008 & 10 & $10,10 \%$ \\
\hline & 99 & $100,00 \%$ \\
\hline
\end{tabular}


Araştırmada incelenen konuların başında lisansüstü tezleri ve makaleleri içine alacak şekilde reklamcılık literatüründe hangi yaklaşımların daha çok kullanıldığını belirlemek gelmektedir. Literatürde değinildiği üzere sosyal bilimlerin bir parçası olarak reklamcılıkta egemen (yönetimsel) ve eleştirel yaklaşımlar kullanılmaktadır. Araştırma kapsamında incelenen lisansüstü tezler ve makaleler olmak üzere toplam 720 yayından \% 65,28'inde egemen yaklaşımlardan, \% 34,72'sinde ise eleştirel yaklaşımlardan yararlanıldığı tespit edilmiştir. Her iki yayın türü arasında karşılaştırma yapıldığında lisansüstü tezlerde ve makalelerde egemen yaklaşımın daha ağırlık kazandığı görülmektedir. Diğer taraftan makaleler arasında egemen ve eleştirel yaklaşımdan yararlanılan çalışmalar arasında çok az bir fark bulunmaktadır. Her iki yayın türünde egemen (yönetimsel) yaklaşımlardan daha fazla yararlanılmasının temel sebebi olarak reklamcılığın uygulamaya dönük bir yapı içermesi ve bu alanda tüketici davranışlarını daha fazla incelemeye ihtiyaç duyulması söylenebilir.

Tablo 4. Reklamcılık Literatüründe Lisansüstü Tezlere ve Makalelere Göre Yararlanılan Yaklaşımlar

\begin{tabular}{|l|c|c|c|c|}
\hline \multirow{2}{*}{$\begin{array}{c}\text { REKLAMCILIK } \\
\text { LiTERATÜRÜNDE } \\
\text { YARARLANILAN } \\
\text { YAKLAȘIMLAR }\end{array}$} & Lisansüstü tez & Makale & TOPLAM & \multirow{2}{*}{ Yüzde } \\
\cline { 2 - 5 } & & & & \\
\hline $\begin{array}{l}\text { Egemen } \\
\text { (Yönetimsel) }\end{array}$ & 418 & 52 & $\mathbf{4 7 0}$ & $65,28 \%$ \\
\hline Eleștirel & 203 & 47 & $\mathbf{2 5 0}$ & $34,72 \%$ \\
\hline \multicolumn{1}{|c|}{ TOPLAM } & $\mathbf{6 2 1}$ & 99 & $\mathbf{7 2 0}$ & $\mathbf{1 0 0 , 0 0 \%}$ \\
\hline
\end{tabular}

Tablo 5'te anabilim dallarında verilen lisansüstü tezlerde üniversite türlerine göre hangi yaklaşımdan yararlanıldığına ilişkin dağılım gösterilmektedir. Bu dağılıma göre, hem devlet $(\% 65,55)$ hem de vakıf $(\% 34,45)$ statüsündeki üniversitelerde sunulan lisansüstü tezlerde egemen yaklaşımın ağırlık kazandığı göze çarpmaktadır. Ayrı ayrı olmak üzere eleştirel $(\% 72,41)$ ve egemen $(\% 65,55)$ yaklaşımdan yararlanılan lisansüstü tezlerin en yoğun olduğu üniversite türü olarak devlet üniversiteleri dikkat çekmektedir.

Tablo 5. Üniversite Türlerine Göre Lisansüstü Tezlerde
Yararlanılan Yaklaşımların Dağılımı

\begin{tabular}{|l|c|c|c|c|}
\hline ÜNivERSiTE TÜRÜ & $\begin{array}{c}\text { Egemen } \\
\text { (Frekans) }\end{array}$ & Yüzde & $\begin{array}{c}\text { Eleștirel } \\
\text { (Frekans) }\end{array}$ & Yüzde \\
\hline Devlet & 274 & $65,55 \%$ & 147 & $72,41 \%$ \\
\hline Vakıf & 144 & $34,45 \%$ & 56 & $27,59 \%$ \\
\hline \multicolumn{1}{|c|}{ TOPLAM } & $\mathbf{4 1 8}$ & $\mathbf{1 0 0 , 0 0 \%}$ & $\mathbf{2 0 3}$ & $\mathbf{1 0 0 , 0 0 \%}$ \\
\hline
\end{tabular}

Tablo 6'da reklamcılık alanındaki lisansüstü tezlerde ve makalelerde yararlanılan yaklaşımların yıllara göre dağılımı verilmiştir. Bu verilere göre, karşımızda yıllar arasında inişli çıkışı bir tablo olsa da hem egemen hem de eleştirel yaklaşımlardan yararlanma bakımından günümüze geldikçe bir artış eğilimi söz konusudur. Bu artışın temel sebebi de yıllar ilerledikçe yapılan çalışmaların sayısındaki 
gözlemlenen artıştır. Egemen $(\% 12,34)$ ve eleştirel $(\% 13,20)$ yaklaşımların en fazla kullanıldığı yıl olarak 2018 yılı ön plana çıkmaktadır. Hangi yıl olursa olsun ağırlık hep egemen yaklaşımda olmuştur. Bu da söylenildiği üzere reklamcılığın uygulama ağırlıklı bir yanı olmasından kaynaklanmaktadır.

Tablo 6. Yıllara Göre Lisansüstü Tezlerde ve Makalelerde Yararlanılan Yaklașımların Dağılımı

\begin{tabular}{|l|l|l|l|l|}
\hline \multicolumn{1}{|c|}{ YIL } & Egemen & \multicolumn{1}{|c|}{ Yüzde } & Eleştirel & \multicolumn{1}{c|}{ Yüzde } \\
\hline 2018 & 58 & $12,34 \%$ & 33 & $13,20 \%$ \\
\hline 2017 & 49 & $10,43 \%$ & 28 & $11,20 \%$ \\
\hline 2016 & 53 & $11,28 \%$ & 23 & $9,20 \%$ \\
\hline 2015 & 45 & $9,57 \%$ & 24 & $9,60 \%$ \\
\hline 2014 & 47 & $10,00 \%$ & 26 & $10,40 \%$ \\
\hline 2013 & 31 & $6,60 \%$ & 24 & $9,60 \%$ \\
\hline 2012 & 40 & $8,51 \%$ & 22 & $8,80 \%$ \\
\hline 2011 & 35 & $7,45 \%$ & 17 & $6,80 \%$ \\
\hline 2010 & 48 & $10,21 \%$ & 21 & $8,40 \%$ \\
\hline 2009 & 38 & $8,09 \%$ & 13 & $5,20 \%$ \\
\hline 2008 & 26 & $5,53 \%$ & 19 & $7,60 \%$ \\
\hline TOPLAM & 470 & $100,00 \%$ & 250 & $100,00 \%$ \\
\hline
\end{tabular}

Araştırma kapsamında incelenen lisansüstü tezler ve makalelerden yola çıkarak Tablo 7'de hangi araştırma yöntemlerinin kullanıldığına dair dağılımlar verilmektedir. Alınan verilere göre her iki yayın türünde en çok faydalanılan araştırma yöntemi \% 45,97 ile nitel araştırma yöntemidir. Onu \% 40,69 ile nicel araştırma yöntemi takip etmektedir. Nitel ve nicel araştırma yöntemlerinin birbirine yakın olması reklamcılığın sosyoloji, felsefe, ekonomi politik gibi alanlardan beslenen disiplinler arası bir özelliğe sahip olmasından hem de tutum ve davranışları belirlemesinden kaynaklanmaktadır. Her iki yöntemin çalışmalarda yer alma oranı ise $\%$ 6,39’dur. Karma yöntemin uygulandığ 1 çalışmalara göre lisansüstü tezlerde, makalelere göre \% 5 daha fazla uygulandığg saptanmıştır. Araştırmacılar tarafından her ne kadar uğraştırıcı olarak görüldüğü için toplam incelenen yayınlar içerisinde düşük bir orana sahip olsa da, biraz önce belirtilen özelliklerden dolayı karma yönteme müsait olduğunu göstermektedir. Her hangi bir yönteme başvurulmayan yayınların oranı ise $\%$ 6,94'tür. 
Tablo 7. Uygulanan Araştırma Yöntemlerinin Dağılımı

\begin{tabular}{|l|c|c|c|c|}
\hline \multirow{2}{*}{$\begin{array}{c}\text { UYGULANAN } \\
\begin{array}{c}\text { ARAȘTIRMA } \\
\text { YÖNTEMLERi }\end{array}\end{array}$} & Lisansüstü tez & Makale & \multirow{2}{*}{ TOPLAM } & YÜZDE \\
\cline { 2 - 5 } & 258 & 35 & 293 & $40,69 \%$ \\
\hline Nicel & 286 & 45 & 331 & $45,97 \%$ \\
\hline Nitel & 43 & 3 & 46 & $6,39 \%$ \\
\hline Karma & & & & \\
\hline $\begin{array}{l}\text { Her hangi bir } \\
\text { yöntem } \\
\text { uygulanmamış }\end{array}$ & 34 & 16 & 50 & $6,94 \%$ \\
\hline \multicolumn{1}{|c|}{ TOPLAM } & $\mathbf{6 2 1}$ & $\mathbf{9 9}$ & $\mathbf{7 2 0}$ & $\mathbf{1 0 0 , 0 0 \%}$ \\
\hline
\end{tabular}

Tablo 8'de ise yukarıdaki Tablo 7'de sunulan araştırma yöntemleri altında kullanılan araştırma tekniklerinin dağılımları verilmiştir. Tabloda incelenen toplam 720 çalışma içerisindeki kullanılan tüm araştırma teknikleri sıralanmaktadır. Elde edilen sonuçlara göre, en çok kullanılan araştırma tekniklerinin başında \% 32,54 ile anket gelmektedir. Onu sırasıyla \% 17,21 ile gösterge bilimsel analiz, $\%$ 14,82 ile içerik analizi, \% 8,29 ile vaka incelemesi, \% 6,53 ile derinlemesine görüşme ve \% 5,78 ile deneysel tasarım takip etmektedir. Anketin araştırma teknikleri arasında en fazla oransal dilime sahip olmasının altında yatan temel faktörün daha önce de belirtildiği üzere, reklamların tüketiciler üzerindeki tutum ve davranışları şekillendirici bir özelliğe sahip olmasından ötürü yapılacak çalışmalara yön verilmek istenmesi olduğudur. Bu da daha çok yönetimsel tarafi ortaya çıkarmaktadır. Toplam incelenen yayın sayısı 720 iken aşağıdaki tabloda 796 çıkmasının sebebi ise bazı çalışmalarda aynı anda birden fazla tekniğe yer verilmesidir. 
Tablo 8. Kullanılan Araștırma Tekniklerinin Dağılımı

\begin{tabular}{|l|c|c|}
\hline \multicolumn{1}{|c|}{ ARAŞTIRMA TEKNIKLERi } & Frekans & Yüzde \\
\hline Anket & 259 & $32,54 \%$ \\
\hline İçerik analizi & 118 & $14,82 \%$ \\
\hline Gösterge bilimsel analiz & 137 & $17,21 \%$ \\
\hline Söylem analizi & 25 & $3,14 \%$ \\
\hline Derinlemesine görüşme & 52 & $6,53 \%$ \\
\hline Betimleyici durum analizi & 6 & $0,75 \%$ \\
\hline Gözlem & 4 & $0,50 \%$ \\
\hline Odak grubu & 16 & $2,01 \%$ \\
\hline Anlatı çözümlemesi & 3 & $0,38 \%$ \\
\hline Vaka İncelemesi & 66 & $8,29 \%$ \\
\hline Psikanalitik analiz & 3 & $0,38 \%$ \\
\hline Deneysel Tasarım & 46 & $5,78 \%$ \\
\hline Etnografi/Netnografi & 1 & $0,13 \%$ \\
\hline Model önerisi & 2 & $0,25 \%$ \\
\hline EEG & 3 & $0,38 \%$ \\
\hline Oyun teorisi & 1 & $0,13 \%$ \\
\hline Yapısal analiz & 1 & $0,13 \%$ \\
\hline Toplum bilimsel çözümleme & 1 & $0,13 \%$ \\
\hline Alımlama analizi & 3 & $0,38 \%$ \\
\hline Her hangi bir teknikten yararlanılmamıştır & $\mathbf{3 9}$ & $6,16 \%$ \\
\hline TOPLAM & & \\
\hline
\end{tabular}

Tablo 9'da, incelenen tüm yayınlarda ele alınan konuların dağılımı verilmiştir. Aşağıdaki tabloda sıralanan konuların hangisinin olduğuna, lisansüstü tezde ve makalede reklamcılığı hangi alt alanla birleştiğine, hangisinin incelenmek istediğine bakılarak karar verilmiştir. Tabloda yansiyan verilere göre, "diğer" olarak sınıflandırılan konular hariç tutulursa tabloda en çok işlenen konuların başında dijital/internet/sosyal medya reklamcılığı gelmektedir. Onu sirasıly tüketim kültürü/toplumu, siyasal reklamcılık, TV reklamı, toplumsal cinsiyet, reklam beğenirliği/tutum ve ürün yerleştirme takip etmektedir. Aşağıdaki tabloda diğer kategorisinin dışında kalan, belirtilen konular en az 10 tane yayın içermesi baz alınarak dahil edilmiştir. Diğer kategorisinde yer alan konular ise 10'un aşağısında kaldığı için diğer başlığı altına yazılmıştır. Diğer başlığı altında olup dikkat çeken konular arasında ise Açıkhava reklamcllığ , advergaming (oyun içinde reklam), cinsellik, viral reklam, sosyal reklam, nöropazarlama, kamu spotları, örtülü reklam yer almaktadır. Bu doğrultuda günümüzde hızla değişen iletişim teknolojilerinin günlük yaşam içine dahil olması ve sosyal medyanın reklamcıllğı değiştirmesi araştırmacıları da bu konuda daha fazla araştırmaya yönelttiğini tablodaki verilerden anlamak mümkündür. 
Tablo 9. Lisansüstü Tezlerde ve Makalelerde İşlenen Konuların Dağılımı

\begin{tabular}{|l|c|c|}
\hline \multicolumn{1}{|c|}{ KONULAR } & Frekans & Yüzde \\
\hline Uluslararası/Küresel Reklamcılık & 20 & $2,78 \%$ \\
\hline Dijital/Internet/Sosyal Medya Reklamcılığı & 69 & $9,58 \%$ \\
\hline Bilinçaltı Reklamcılık/Gizli Reklam & 16 & $2,22 \%$ \\
\hline Siyasal Reklamcılık & 33 & $4,58 \%$ \\
\hline Mobil Reklamcılık & 11 & $1,53 \%$ \\
\hline Toplumsal Cinsiyet & 27 & $3,75 \%$ \\
\hline Reklam Tasarımı/Grafik Tasarım & 15 & $2,08 \%$ \\
\hline Marka İletişimi/Imajı & 16 & $2,22 \%$ \\
\hline Reklamda Yaratıcılık & 12 & $1,67 \%$ \\
\hline Ürün yerleştirme & 23 & $3,19 \%$ \\
\hline Reklam Beğenirliliği/Tutum & 25 & $3,47 \%$ \\
\hline TV Reklamı & 28 & $3,89 \%$ \\
\hline Reklamda etkililik/etkinlik & 14 & $1,94 \%$ \\
\hline Basın ilanı/reklamı & 17 & $2,36 \%$ \\
\hline Yeşil/çevresel reklam & 13 & $1,81 \%$ \\
\hline Ünlü kullanımı & 14 & $1,94 \%$ \\
\hline Tüketim kültürü/toplumu & 43 & $5,97 \%$ \\
\hline Reklam ajansları/reklam sektörü & 13 & $1,81 \%$ \\
\hline Reklam Denetimi/Hukuku & 301 & $1,39 \%$ \\
\hline Diğer & & $41,81 \%$ \\
\hline \multicolumn{1}{|c|}{ TOPLAM } & $100,00 \%$ \\
\hline
\end{tabular}

Tablo 10'da, incelenen tüm lisansüstü tezler ve makaleler içerisinde yer verilen anahtar kelimelerin dağılımı görülmektedir. Anahtar kelimeler, araştırma sürecinde irdelemek istediğimiz konuya yönlendiren ve çalıştığımız konu bağlamındaki yayınlara ulaşmamızı sağlayan yardımcı unsurlardır. Bu unsurların tabloda ne kadar dağılıma sahip olduğu, hangi konuların daha yoğun işlendiğine dair işaret vermektedir. Yine bir önceki tablodaki gibi frekansı 10'un aşağısında kalan anahtar kelimeler diğer kategorisine dahil edilmiştir. Buna göre toplam tespit edilen 2.000 anahtar kelime içerisinde, diğer kategorisi haricinde, \% 14,55 ile reklam/reklamcılık ilk sırayı almaktadır. En fazla bu anahtar kelimenin yer alması çalışmanın reklamcılık literatürü ile ilgili analize tabi tutulmasındandır. Onu \% 6,45 ile tüketici davranışları/tutumları, \% 4,95 ile dijital/internet/sosyal medya reklamcılı̆̆ ve \% 3,65 ile marka/marka imajı takip etmektedir. İkinci sırada tüketici davranışları/tutumlarının takip etmesi, yönetimsel yaklaşımı ve anket araştırma tekniğinin daha fazla içermesiyle paralellik gösterirken, üçüncü sırada dijital reklamcılığın yer alması bir önceki tabloda yansıyan en fazla işlenen konu olmasıyla tutarlılık içindedir. Tüketici davranışları veya dijital reklamcılık konularında da anahtar kelimelerde "reklam" ibaresine yer verilmesi en fazla oranı bu anahtar kelimenin çıkmasına neden olmaktadır. 
Tablo 10. Lisansüstü Tezlerde ve Makalelerde Yer Verilen Anahtar Kelimelerin Dağılımı

\begin{tabular}{|c|c|c|}
\hline ANAHTAR KELIMELER & Frekans & Yüzde \\
\hline Küreselleşme/küresel reklamcılık & 26 & $1,30 \%$ \\
\hline Küreyerel reklam & 11 & $0,55 \%$ \\
\hline Dijital/internet reklamcılığı/sosyal medya/interaktif & 99 & $4,95 \%$ \\
\hline Görsel Tasarım/Grafik tasarım & 38 & $1,90 \%$ \\
\hline Reklam yaratıcı/mesaj stratejileri & 23 & $1,15 \%$ \\
\hline Reklamcılık/reklam & 291 & $14,55 \%$ \\
\hline Göstergebilim & 73 & $3,65 \%$ \\
\hline Kültür/kültürel değerler & 28 & $1,40 \%$ \\
\hline Reklamda etkililik/verimlilik & 18 & $0,90 \%$ \\
\hline Pazarlama/Bütünleşik/Pazarlama iletişimi & 39 & $1,95 \%$ \\
\hline Postmodernizm & 16 & $0,80 \%$ \\
\hline Reklam yönetimi & 10 & $0,50 \%$ \\
\hline Tüketici/tüketici davranışları/tutumları & 129 & $6,45 \%$ \\
\hline Tüketim/tüketim toplumu/kültürü & 69 & $3,45 \%$ \\
\hline Bilinçaltı mesajlar/reklamcılık & 31 & $1,55 \%$ \\
\hline Siyasal reklamcılık/kampanya/iletişim & 36 & $1,80 \%$ \\
\hline İkna & 17 & $0,85 \%$ \\
\hline Açıkhava reklamcılığı & 12 & $0,60 \%$ \\
\hline Mobil reklamcılık & 10 & $0,50 \%$ \\
\hline Toplumsal cinsiyet & 22 & $1,10 \%$ \\
\hline Etik & 19 & $0,95 \%$ \\
\hline Reklam denetimi/hukuku & 15 & $0,75 \%$ \\
\hline Algı/algılama & 12 & $0,60 \%$ \\
\hline Reklam söylemi/dili & 13 & $0,65 \%$ \\
\hline Marka/marka iletişimi/imajı & 73 & $3,65 \%$ \\
\hline Ürün yerleştirme & 25 & $1,25 \%$ \\
\hline TV Reklamı/TV/film & 70 & $3,50 \%$ \\
\hline Basın ilanları/reklamları & 29 & $1,45 \%$ \\
\hline Sinema/Sinema Pazarlaması & 10 & $0,50 \%$ \\
\hline Temsil/Sosyal temsil & 12 & $0,60 \%$ \\
\hline Reklam çekicilikleri & 11 & $0,55 \%$ \\
\hline Kurumsal imaj/reklamcılık & 19 & $0,95 \%$ \\
\hline Ünlü kullanımı & 14 & $0,70 \%$ \\
\hline Yeşil reklam/pazarlama & 14 & $0,70 \%$ \\
\hline İmge/Imaj & 13 & $0,65 \%$ \\
\hline Medya & 16 & $0,80 \%$ \\
\hline Kadın & 24 & $1,20 \%$ \\
\hline Çocuk & 15 & $0,75 \%$ \\
\hline Diğer & 598 & $29,90 \%$ \\
\hline TOPLAM & 2000 & $100,00 \%$ \\
\hline
\end{tabular}


Tablo 11, araştırma kapsamında incelenen lisansüstü tezlerin hangi anabilim dalı altında çıktığı konusunda bilgi vermektedir. Tabloda yansıyan veriler ışığında, \% 22,38 oranla en fazla lisansüstü tezin yayınlandığı anabilim dalı halkla ilişkiler ve tanıtım olmuştur. Onu sırasıyla \% 14,33 ile işletme/işletme yönetimi, \% 12,40 ile diğer anabilim dalları takip etmektedir. Halkla İlişkiler ve Tanıtım anabilim dalının Halkla İlişkiler ile Reklamcılık bölümlerini içermesiyle bu alanda tezlerin en fazla çıkmasının beklendiği anabilim dalı olmuştur. Tablo incelendiğinde aslında çeşitli ve farklı anabilim dallarının olduğu dikkat çekmektedir. Tabloda adı geçenler arasında Grafik Anasanat, Medya ve İletişim Çalışmaları, Radyo-TV-Sinema ve Gazetecilik ile beraber diğer kategorisi altında adı geçmeyen Ekonometri, Kadın Çalışmaları, Sağlık Yönetimi, Sosyoloji, Yönetim Bilişsim Sistemleri gibi anabilim dalları göze çarpmaktadır. Bu tablo aslında reklamcılık alanının disiplinler arası bir geçişte bulunduğunu ve diğer alanlardan oldukça beslendiğini açıkça ortaya koymaktadır.

Tablo 11. Lisansüstü Tezlerin Yayımlandığı Anabilim Dallarının Dağılımı

\begin{tabular}{|c|c|c|}
\hline $\begin{array}{l}\text { LiSANSÜSTÜ TEZIN YAYIMLANDIĞI } \\
\text { ANABILIM DALI }\end{array}$ & Frekans & Yüzde \\
\hline Gazetecilik/Genel Gazetecilik & 13 & $2,09 \%$ \\
\hline Grafik Anasanat/Resim/Güzel Sanatlar & 41 & $6,60 \%$ \\
\hline Halkla İlişkiler & 40 & $6,44 \%$ \\
\hline Halkla İlişkiler ve Tanıtım & 139 & $22,38 \%$ \\
\hline $\begin{array}{l}\text { Halkla İlişkiler ve Reklamcılık/ } \\
\text { Reklamcılık ve Halkla İlişkiler }\end{array}$ & 48 & $7,73 \%$ \\
\hline $\begin{array}{l}\text { İletişim ve Tasarım/ } \\
\text { İletişim Tasarımı Yönetimi }\end{array}$ & 23 & $3,70 \%$ \\
\hline İletişim/Iletişim Bilimleri & 51 & $8,21 \%$ \\
\hline İşletme/Yönetimi & 89 & $14,33 \%$ \\
\hline Medya ve İletişim/Kültürel Çalışmaları & 14 & $2,25 \%$ \\
\hline Radyo-TV-Sinema & 26 & $4,19 \%$ \\
\hline Reklamcılık & 28 & $4,51 \%$ \\
\hline Reklamcılık ve Marka Yönetimi/Iletişimi & 32 & $5,15 \%$ \\
\hline Diğer & 77 & $12,40 \%$ \\
\hline TOPLAM & 621 & $100,00 \%$ \\
\hline
\end{tabular}

Araştırma süresince incelenen lisansüstü tezlerin ve makalelerin yayım dili incelendiğinde \% 92,50'lik oranla Türkçe başı çekmektedir. Geriye kalan \% 7,50'lik kısmı ise İngilizce, Almanca ve Fransızca olarak dağılmaktadır. Bunlar arasında da yabancı dilde İngilizce ön plana çıkmaktadır. Yabancı dil olarak çoğunlukla lisansüstü tezlerde ve makalelerde İngilizce bir seçenek olarak kullanılmaktadır. İngilizce ile eğitim yapan anabilim dallarının bunda önemli bir payı bulunmaktadır. 
Tablo 12. Yayımlanan Lisansüstü Tezlerin ve Makalelerin Dili

\begin{tabular}{|c|c|c|}
\hline YAYIMLANAN TEZIN DiLi & Frekans & Yüzde \\
\hline Türkçe & 666 & $92,50 \%$ \\
\hline İngilizce & 50 & $6,94 \%$ \\
\hline Almanca & 2 & $0,28 \%$ \\
\hline Fransizca & 2 & $0,28 \%$ \\
\hline TOPLAM & 720 & $100,00 \%$ \\
\hline
\end{tabular}

\section{Sonuç}

Stratejik bir iletişim yönetimi olan reklamcılık mesleğine nitelikli eleman yetiştirme ve bu alanda teorik ve pratik bilgi üretimini sağlama amacıyla Türkiye'de yirminci yüzyılın son çeyreğinde başlayan reklamcılık eğitiminin yüzyılın sonlarına doğru olgunlaştığı ve özellikle son 10 yılda ülkenin hemen her bölgesine yayılarak verildiği görülmektedir. Reklamcılık eğitiminin yaygınlaşmasıyla birlikte söz konusu bu eğitimin nasıl olması gerektiğini nitel ve nicel açıdan değerlendiren çalışmalar da yapılmaya başlamıştır. Literatürde bu tarz çalışmalara sıklıkla rastlamak mümkündür. Bu çalışma ise reklamcılık eğitiminin bir çıktısı olan lisansüstü tezlerinin ve aynı zamanda hakemli dergilerde yayımlanan makalelerin konulara göre tasnifini yaparak bu çalışmaların reklamcılık alanına katkısının ne düzeyde ve ne sıklıkta olduğunu tespit etmek amaciyla gerçekleştirilmiştir.

Türkiye'de 2008-2018 yıları arasında tamamlanmış lisansüstü (yüksek lisans/doktora) tezlerinin ve ulusal makalelerin bibliyometrik bir çözümlemesinin yapıldığı bu çalışmayla reklamcılık literatüründeki araştırmalarının genel özellikleri ve yönelimleri ortaya konulmaya çalışılmıştır.

Araştırma sonucunda reklam araştırmalarında hem nicelik hem çeşitlilik bağlamında açık bir hareketliliğin olduğu görülmektedir. 2010'lu yıllarla beraber reklam araştırmalarının sayısında önemli bir artışın başladığı, bu artışın dönemin ortalarında giderek hızlandığı, yaklaşık 10 yıllık bir zaman dilimine yayılan lisansüstü tezlerin yaklaşık yarısının son beş yılda yazılmış olmasından anlaşılmaktadır.

Bunun yanında yeni konu ve yaklaşımların denenmeye çalışıldığı, reklam araştırmalarının daha disiplinler arası bir nitelik kazanma yöneliminde olduğu tespit edilmiştir. Bu yönelim 1990'ların ortasında başlayarak gelişmekle birlikte 2000'lerden itibaren ivme kazanmıştır. Farklı disiplinlere bağlı anabilim ve ana sanat dallarında çalışan araştırmacıların reklam araştırmalarına olan ilgisinin gün geçtikçe artmakta olduğu görülmektedir. Başlangıçta yalnızca halkla ilişkiler, reklam, iletişim bilimleri gibi reklamcılıkla öteden beri yakın ilişki içinde olduğu bilinen alanlarda reklamcılık tezlerine rastlanırken; 2010'lu yıllardan itibaren sosyoloji, hukuk, edebiyat, ekonomi, mühendislik gibi daha uzak kabul edilebilecek akademik disiplinlerde de reklamcılığı ele alan lisansüstü araştırmalara yönelindiği görülmektedir. 
Reklamcılık alanında 2008-2018 yılları arasında yazılan 621 lisansüstü tezinin ve ulusal hakemli dergilerde yayımlanan makalelerin ana kategorilere göre konu dağılımlarına bakıldığında en çok “diğerleri” kategorisinde çalışmaların görülmektedir. Bu durum reklamcılığın disiplinler arası bir alan olduğuna vurgu yapar niteliktedir. Öyle ki, siyaset, felsefe, turizm, sosyoloji gibi alanların da reklam alanıyla bir şekilde temas etmesi ve bu alanlarda da reklam konularıyla bağlantılı tezlerin ve makalelerin yazılması bu durumun en somut örneğidir.

Araştırma kapsamında incelenen tezlerin ve makalelerin reklamcılık literatürüne dayalı kategorik dağılımına bakıldığında ise en fazla "dijital/sosyal medya reklamcıllğı" kategorisinde yazıldığı görülmektedir. Bu durum reklamcılık uygulama alanlarında yaşanan değişimi ve gelişimi gösterir niteliktedir. Özellikle iletişim teknolojilerinde yaşanan gelişmeler neticesinde stratejik bir iletişim yönetimi olan reklamcılık alanına yeni uygulama alanlarının eklenmesi ve dijital reklamcılık faaliyetlerinin artması araştırma konularının bu alt kategoride yoğunlaşmasına neden olmuştur. $\mathrm{Bu}$ kategorinin en fazla çıkmasının bir diğer nedeni ise son birkaç yıldır reklam verenlerin tüketicilerle iletişim sürecinde daha hızlı ve kolay ulaşabilmesi adına sosyal medya ve diğer dijital platformları tercih etmesine bağlanabilir. Dolayısıyla yeni bir uygulama alanı olması ve araştırılabilecek yeni alt alanlar çıkarması araştırmacıları tutum ve davranışları anlamak için bu yöne itmektedir. Bu alt kategoriden sonra en fazla "tüketim toplumu/kültürü” kategorisinde çalışmaların yapıldığı görülmektedir. Böylesine bir yönelimi ise reklamın toplumsal gelişmeleri oldukça etkilemesine ve aynı şekilde sosyal değişimlerden etkilenmesine bağlamak mümkündür. Reklamın kendi yapısı gereği ideolojik ve sembolik anlamlar sunması bu alt alanda da oldukça araştırılacak başlıklar çıkarmaktadır.

Araştırma kapsamına dahil edilen reklamcılık alanındaki lisansüstü tezlerde ve makalelerde yararlanılan yaklaşımların önemli bir ağırlı̆̆ını egemen (yönetimsel) yaklaşım oluşturmaktadır. Kullanılan araştırma tekniklerinde en fazla anketin kullanılması da bu durumu desteklediği düşünülmektedir. $\mathrm{Bu}$ tablo doğal olarak reklamcılık alanının işlevsel/uygulamalı yapısı nedeniyle beklenen bir sonuç olarak ortaya çıkmaktadır. Anket tekniğinin nicel araştırma yöntemi altında uygulanıyor olmasından dolayı, nicel araştırma yönteminin nitel araştırma yönteminin üzerinde olması beklenirken, nitel araştırma yönteminin \% 5 kadar bir farkla öne çıkması dikkati çeken diğer bir husus olarak karşımıza çıkmaktadır. Her ne kadar böyle bir tablo gözükse de nitel ve nicel araştırma yönteminin oransal dağılımının birbirine çok yakın olması, reklamcılığın uygulamalı bir alan olduğu kadar sosyolojik, felsefi ve ekonomi-politik alanlardan beslendiğini ve diğer alanlar arasında geçişkenlik sağladığını göstermektedir.

Buna ek olarak reklamcılık alanında yazılan lisansüstü tezlerinin büyük çoğunluğunun devlet üniversiteleri bünyesinde yazıldığı görülmektedir. Egemen (yönetimsel) ve eleştirel yaklaşımlarının benimsendiği lisansüstü tezlerin en çok çıktı̆̆ı üniversitelerin büyük bir kısmını yine devlet üniversiteleri oluşturmaktadır. Buradan hareketle devlet üniversiteleri bünyesinde yazılan tezlerin reklamcılık alanına, vakıf üniversitelerine göre daha fazla katkı sağlaması bu kısıtlı veride görülse bile 
İstanbul merkezli Vakıf üniversitelerinde uygulama yöneliminin yoğun olduğu; çalışma kapsamı tezsiz programlardaki dönem projeleri ile lisans düzeyindeki bitirme tezlerine genişletildiğinde tablonun değişmesi öngörülebilir. Bundaki temel sebebin vakıf üniversitelerinin devlet üniversitelerine göre lisansüstü programların yapılanmasına daha geç başlaması ve yeterli akademik kadronun istenilen seviyede olmaması söylenebilir.

Çalışmada sadece 2008-2018 yılları arasında yayımlanan lisansüstü tezlerin ve makalelerin bibliyometrik özellikleri açısından incelenmiş olması bu çalışmanın bir sınırlılı̆̆ıdır. Ayrıca araştırma kapsamına yalnızca YÖK veri tabanında kayıt altına alınmış tezlerin dahil edilmesi, henüz internet adresine veri girişi yapılmayan tezlerin kapsam dışı kalmasına neden olmuş olabilir. Bundan sonra yapılacak araştırmalarda reklamcılık alanı ile ilgili ulusal ve uluslararası kongrelerde yayınlanan bildiriler ve ilişkin araştırmalar da dahil edilebilir. Yeni çalışmalarda bildiriler, makaleler ve tezler karşılaştırmalı olarak değerlendirilebilir. Ayrıca gelecek yıllarda reklamcılık alanında hazırlanan makale, bildiri ve tezlerin bibliyometrik açıdan değerlendirileceği araştırmalar ile yıllar itibariyle karşılaştırma yapma olanağı da elde edilecektir. Buna karşılık her iki yayın için de şunu söylemek gerekirse, başlık veya anahtar sözcüklerde geçmese de, en azından işletme-pazarlama alanında, hipotetik veya gerçek reklamlar üzerine kurgulanan ve buna göre tasarlananların bulunduğu ifade edilebilir. Dolayısıyla bunun da araştırmada muhtemel kayıp veriye yol açtığını altını çizmek gerekmektedir. 


\section{Kaynakça}

Al, Umut ve Coştur, Recai (2007) “Türk Psikoloji Dergisinin Bibliyometrik Profili”, Türk Kütüphaneciliği, 21.2, ss. $142-163$.

Broadus, Robert N. (1987) “Toward a Definition of Bibliometrics”, Scientometrics, 12.5-6, ss. 373-379.

Çetinkaya, Özlem \& Çetin, Ali (2016) “Girişimcilik ve Kalkınma Dergisi’nin Bibliyometrik Analizi”, Girişimcilik ve Kalkınma Dergisi, 11.2, ss. 229-263.

Dağtaş, Banu (2009) "Reklamları Görmek: Reklam Metinlerinin Ait Olduğu Kültürler ve Egemen Form Olarak Tüketim Kültürü”, Derya Tellan (Drl.); Reklamcllı: Bakmak ve Görmek, Ütopya Yayınları, Ankara, ss. 46-78.

Dyer, Gillian (1982) Advertising as Communication, Methuen, London.

Elden, Müge; Ulukök, Özkan ve Yeygel, Sinem (2005) Şimdi Reklamlar..., İletişim Yayınları, İstanbul.

Erdoğan, İrfan ve Alemdar, Korkmaz (2002) Öteki Kuram: Kitle İletişimine Yaklaşımların Tarihsel ve Eleştirel Bir Değerlendirmesi, Erk Yayınları, Ankara.

Leiss, William, Kline, Stephen ve Jhally, Stuart (1990) Social Communication in Advertising, Persons, Products and Images of Well-Being, Routledge, London.

Melody, William H. ve Mansell, Robin E. (1983) “The Debate over Critical vs. Administrative Research: Circularity or Challenge", Journal of Communication, 33.3, ss. 103-116.

Mutlu, Erol (2012) İletişim Sözlüğ̈̈, Sofos Yayınları, Ankara.

Murdock, Graham (1993) "Communications and the Constitution of Modernity", Media, Culture and Society, 15.4, ss. 521-539.

Özel, Hale \& Kozak, Nazmi (2012) “Turizm Pazarlaması Alanının Bibliyometrik Profili (2000- 2010) ve Bir Atıf Analizi Çalışması”, Türk Kütüphaneciliği, 26.4, ss. 715-733.

Pritchard, Alan (1969) “Statistical Bibliography or Bibliometrics?", Journal of Documentation, 25.4, ss. 348349.

Sherry, John F. (1987). "Advertising as a Cultural System”, J. U. Sebeok (Ed.); Semiotic Marketing, Mouton de Gruyter, Berlin, ss. 441-458.

Slack, Jennifer D. ve Allor, Martin (1983) "The Political and Epistemological Constituent of Critical Communication Research”, Journal of Communication, 33.3, ss. 208-218.

Williams, Raymond (1981) Culture, Fontana, London.

Wunderlich, Jens-Uwe ve Warrier, Meera (2007) A Dictionary of Globalization, Routledge, London.

Yaşın, Cem; Çetin, Muharrem ve Sönmez, Büşra (2017) "Halkla İlişkiler Alanındaki Doktora Tezleri Üzerinden Türkiye ve ABD’de Bilimsel Bilginin Gelişiminin Analizi”, Selçuk İletişim Dergisi, 10.1, ss. 454-480.

Yaylagül, Levent (2010) Kitle İletişim Kuramları: Egemen ve Eleştirel Yaklaşımlar, Dipnot Yayınları, Ankara.

Yıldırım, Ali ve Şimşek Hasan (2005) Sosyal Bilimlerde Nitel Araştırma Yöntemleri, 5. Baskı, Seçkin Yayıncılık, Ankara.

Yılmaz, Ahmet (2002) "Reklamın Etkisini Ölçmede Kullanılan Modeller”, Pazarlama İletişimi Dergisi 2.2, ss. 42-48.

Zan, Burcu Umut (2012) “Türkiye'de Bilim Dallarında Karşılaştırmalı Bibliyometrik Analiz Çalışması”, Yayınlanmamış Doktora Tezi, Ankara Üniversitesi, Ankara, Türkiye. 